\title{
An Empirical Analysis of Bilingual Teaching in Mechanical Specialty
}

$$
\text { Lihua Guo }{ }^{1, a^{*}} \text {, Ziyang Cao }{ }^{1, b} \text {, Jianfeng Yang }{ }^{1, c} \text { and CK Tan }{ }^{2, d}
$$

${ }^{1}$ School of Mechanical Engineering, Suzhou University of Science and Technology, 215009, Suzhou, China

${ }^{2}$ School of Computing, Engineering and Science, University of South Whales, CF37 1DL, Pontypridd, UK

alihuaguo2008@163.com, bdukeczy@nuaa.edu.cn, 'yjf0315@163.com, 'ck.tan@southwales.ac.uk

* The Corresponding author

Keywords: Blingual teaching; Mechanical specialty; University of south wales

\begin{abstract}
Bilingual teaching plays an important role in accelerating the process of internationalization of higher education and cultivating highly qualified talents with international competitiveness. Bilingual teaching has always been one of the hotspots of teaching reform in our country and one of the focuses of experts and scholars. This paper designed Eight questions about the bilingual teaching mode of English proficiency, professional interest, teaching style, classroom atmosphere, lesson plan design, English promotion, mastery of professional knowledge, teaching effect and preference of bilingual teaching. This paper analyzed the advantages and disadvantages of the two kinds of teaching modes, such as the teaching in short term by UK's lecturer and teaching by the school professional teachers, and put forward the solution to the existing problems.
\end{abstract}

\section{The Necessity and Importance of Bilingual Teaching}

In the course of teaching higher education in China, bilingual teaching is a kind of teaching mode which is taught in Chinese and English bilingual and even English as the main teaching language [1]. Applicants are Chinese college students, especially international cooperative students. In response to the needs and challenges of internationalization of higher education in the economic globalization, the Council of Cultural Cooperative Education of Europe formulated the "European Language Common Reference Framework: Learning, Teaching and Evaluation" in 2008, incorporating bilingual English teaching; foreign scholars began the study of bilingual teaching from the 1980s with the conclusion that English is the main tool for the publication and exchange of academic achievements[2]. Whether the teaching language is English or mother tongue, students need to search literature in English, participate in international academic exchanges and Writing essays in English. Therefore, English are indispensable important tools[3].

Suzhou University of Science and Technology is located in the economically developed city of Suzhou, which has tens of thousands of European and American enterprises. The students have great chances to find jobs in foreign companies. However, foreign companies only need international talent with good English level and proficiency in professional knowledge.

The school of mechanical design and automation (international cooperation) began to recruit students in September 2012. Under united training with the University of South Wales, the students study in China's school for three years. At the last year, the IELTS exam pass students can apply for a year to study in the UK.

\section{Comparison of Bilingual Teaching Modes}

At present, two modes are adopted for bilingual teaching: teaching in short term by UK's lecturer and teaching by the school professional teachers.

Teaching in Short Term by UK's Lecturer. At every semester, there is one special course taught by full-time faculty from the University of South Wales with one Chinese auxiliary teacher. The 
teaching of the course is taught in two weeks. Using the English language teaching, Foreign teachers' teaching content, teaching methods are the same as the United Kingdom. Chinese teaching assistants mainly complete the teaching content of the preview and teaching counseling, teaching materials finishing. Under This mode, the students have two weeks completely immersed in the English environment, can greatly improve the comprehensive ability of English.

Teaching by the School Professional Teachers. Each semester has a professional course by the school professional teachers to complete bilingual teaching. In the teaching process, textbook, teaching methods and teaching ideas all are determined by the professional teacher. In teaching, the ratio of English to Chinese is not less than $50 \%$, which is a basic requirement. In this teaching mode, the general textbook is used English teaching materials. Teaching methods and teaching philosophy are the same as the general course, and the main language in teaching mainly depends on the teacher's English level.

\section{The Experimental Demonstration of the Effectiveness of Teaching}

Teaching Experimental Design. The sophomore majoring in international education institute of machinery are selected to study the two bilingual courses "Engineering Thermodynamics" and "Mechanical Design". Among them, "Engineering Thermodynamics" is completed by the British teachers using pure foreign language centralized teaching model," mechanical design "is taught by Chinese professional teachers using bilingual teaching.

The teaching experiment was conducted in the form of questionnaires, and eight questions of English language proficiency, professional interest, teaching methods, classroom atmosphere, lesson plans, English promotion, mastery of professional knowledge, teaching effect and preference of bilingual teaching were designed. The design of the questionnaire is as table 1[4].

Table 1 Eight questions of questionnaires

\begin{tabular}{|c|c|}
\hline English Language Proficiency & Poor, General, good, skilled, proficient \\
\hline Professional Interest & Extremely interested, interested, general, not interested \\
\hline Teaching Methods & $\begin{array}{c}1 \text { international exchange foreign teacher } \\
\text { 2 Chinese professional teacher }\end{array}$ \\
\hline Classroom Atmosphere & $\begin{array}{c}\text { 1 international exchange foreign teacher } \\
2 \text { Chinese professional teacher }\end{array}$ \\
\hline Lesson Plans & $\begin{array}{c}1 \text { international exchange foreign teacher } \\
\text { 2 Chinese professional teacher }\end{array}$ \\
\hline English Promotion & $\begin{array}{c}\text { 1 international exchange foreign teacher } \\
\text { 2 Chinese professional teacher }\end{array}$ \\
\hline Mastery of Professional Knowledge & $\begin{array}{c}1 \text { international exchange foreign teacher } \\
\text { 2 Chinese professional teacher }\end{array}$ \\
\hline Preference of Bilingual Teaching & $\begin{array}{c}1 \text { international exchange foreign teacher } \\
\text { 2 Chinese professional teacher }\end{array}$ \\
\hline
\end{tabular}

\section{Analysis of Teaching Expecriment}

Analysis of Teaching Object.This paper analyzed the mechanical sophomore students of international cooperative mode. International cooperative mode uses different training programs for mechanical professional and general mechanical professional. International cooperative mode increases the classes for English teaching. In addition to public English, there are specialized listening and speaking IELTS courses. According to the survey results shown as Fig.1 and Fig.2, 70\% of the students are better in English. There is no obvious language barrier for sophomore to learn the courses of foreign teachers. $40 \%$ of the students are more interested in the mechanical profession and $15 \%$ of 
the students are very uninterested in the mechanical profession. Most of the students can do a serious listening of the two courses.

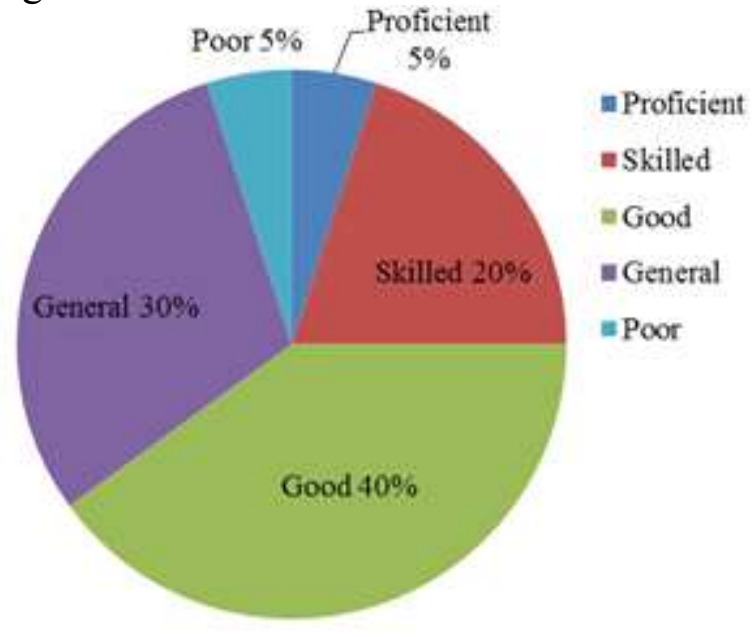

Figure 1. Finite English Language Proficiency

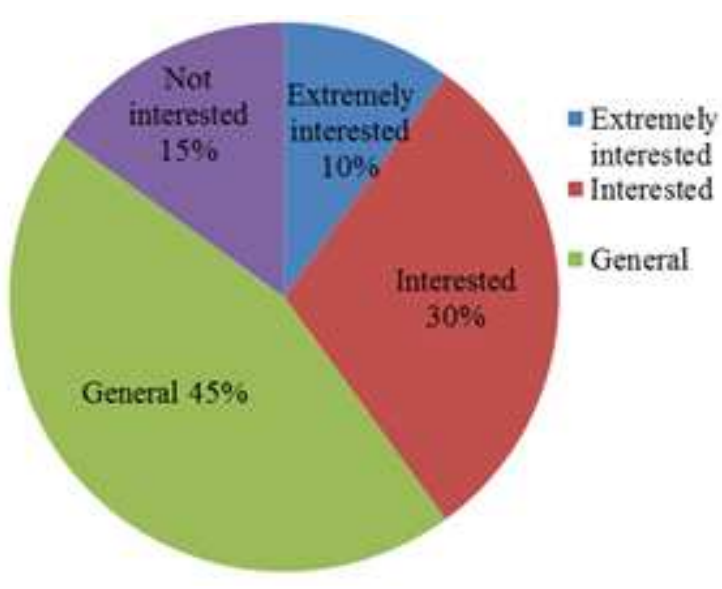

Figure 2. Finite Professional Interest

Analysis of Teaching Effect.The questionnaire survey designed six kinds of questions, teaching methods, classroom atmosphere, lesson plans, English promotion, and mastery of professional knowledge and tendencies of bilingual teaching mode. The teaching effects Comparison has been done between of two teaching modes from the six types of questions.

It can be seen from the Fig .3 that the teaching mode of foreign teacher is better than that of the professional teacher in the teaching methods and classroom atmosphere. There is almost no difference for the teaching plan of the two teaching modes. The teaching mode of foreign teacher is much better than professional teacher on English improving. However, in the mastery of professional knowledge, teaching mode of professional teacher is significantly better than short term teaching mode of foreign teachers. Finally, students tend to focus teaching mode of foreign teacher.

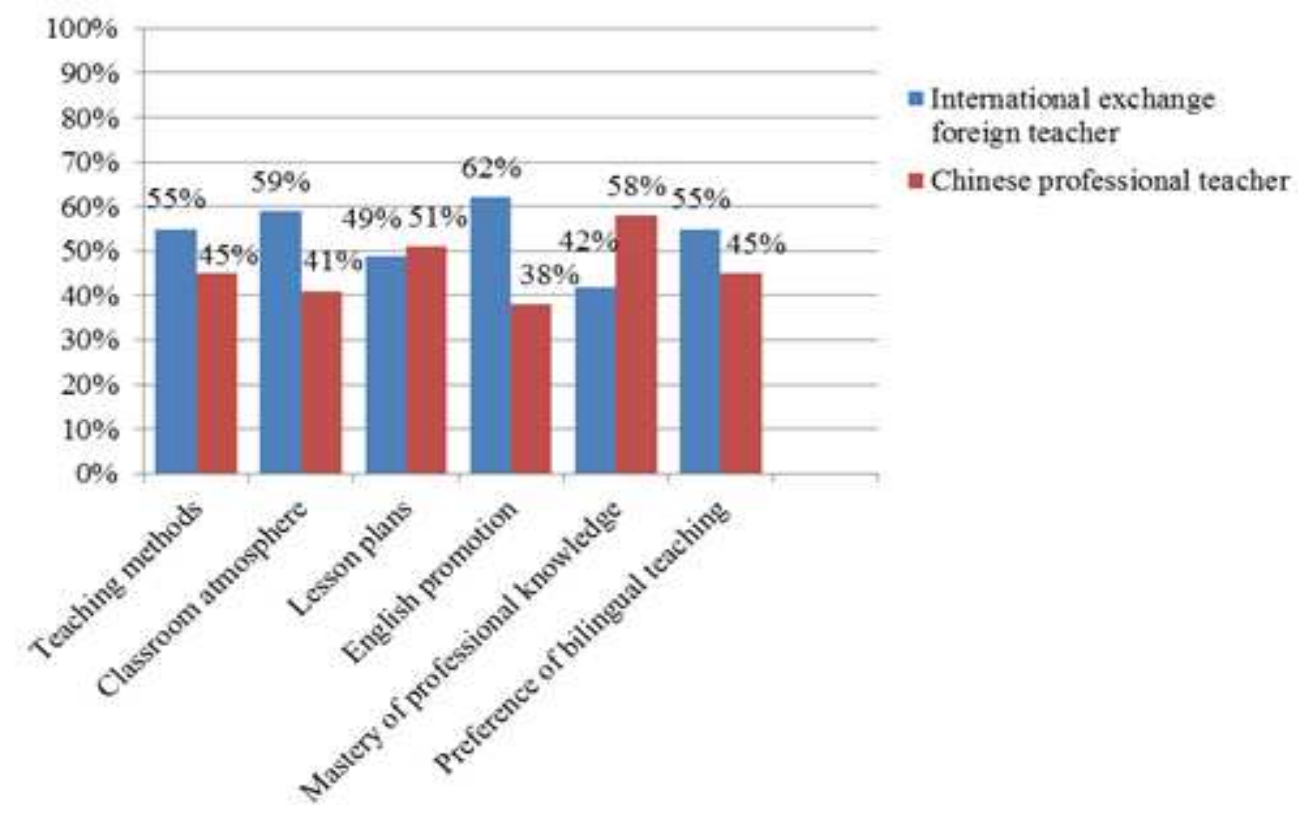

Figure 3. Finite Analysis of Teaching Effect

\section{Analysis of Existing Problems}

Textbook Problem. In the United Kingdom, colleges and universities generally do not give specify text books, teachers refer to a number of teaching materials to write their own notes according to the syllabus. Domestic students can't adapt to the teaching mode without text book. It is also difficult to 
borrow the reference books which used by foreign teacher from the domestic library. Meanwhile, Chiniese professional teachers, usually use domestic teaching materials or translated foreign textbooks in bilingual teaching. The quality of textbooks translated is often not so accurate. As for some of the domestic college textbooks, professional is not strong, lack of precision language, and they are not suitable for widely use by the university[5].

Professional teachers' English Proficiency Level. Bilingual teaching requires the teachers to have strong English listening, speaking, reading and writing skills. In particular, teachers' spoken English should be very good and proficient in using English to communicate with students. Overall, bilingual teaching requires teachers to have strong English level. Bilingual teaching by professional teachers will be the main mode in our school. Although these teachers have strong professional skills, English teaching is relatively difficult for them. Many of them rely on their own self-study and lack systematic training. Teachers said that in the deep exchange with the students, they feel powerless due to their limited level of English. It can be seen that the lack of English proficiency is a major bottleneck restricting the development of bilingual teaching in universities [6].

\section{Conclusions}

Bilingual teaching can help improve the quality of students and cultivate international talents. For students who plan to go abroad, they can improve their English reading ability, listening ability and expressive ability through bilingual learning, and better adapt to foreign teaching mode and integrate into foreign study.

Bilingual teachers should change the original teaching model, the use of international advanced flip classroom mode and change the teaching method to improve students' learning initiative and enthusiasm. Using lectures and reporting mode to provide opportunities for students to speak more English and train English thinking mode.

Universities actively create a campus language environment and the school environment to improve students' English level. Schools should increase the intensity of library and reference room, purchase advanced foreign language books and magazines, to ensure that students can easily access to the latest foreign original books. Secondly teachers in the bilingual class as much as possible to use fluent English to communicate with students, and encourage students to actively participate.

\section{Acknowledgements}

This research is supported by the teaching reform and research project of Suzhou University of Science and Technology in 2015(2015JGM-20) and international cooperation in high level demonstration construction project of Jiangsu province in 2016(2016-17).

\section{References}

[1] Z.L.Liu, Y.Luo and H.Y.Hu: China University Teaching, (2012)No.5, p.58(In Chinese)

[2] X.P.Xu: Heilongjiang Researches on Higer Education, (2016)No.4, p.37(In Chinese)

[3] H.P.Zheng: Journal of Southwest China Normal University(Natural Science Edition), Vol.42(2017)No.3, p174(In Chinese)

[4] S.L.Tao: Journal of Peking University (Philosophy and Social Sciences), (2007)No.5, p17(In Chinese)

[5] H.Y.Jiang, H.M.Li, C.M.Hu. Higher Education Exploration, (2007)No.6, p22(In Chinese)

[6] L.Yang, J.Zheng and J.Peng: Experimental Technology and Management, Vol.32(2015)No.10, p182(In Chinese) 